Kai Dröge \& Olivier Voirol

\title{
Online dating: The tensions between romantic love and economic rationalization
}

\section{Online-Dating zwischen romantischer Liebe und ökonomischer Rationalität}

\begin{abstract}
:
This paper will at first show how romantic love and economic rationality have emerged in modernity as two distinct spheres, which are characterized by their own normative principles, expectations and practical orientations - two spheres that have systematically been opposed in sociological tradition. In a second part, it will be analyzed how these two distinct sets of normative principles and practical orientations are both introduced into the field of online dating. This leads to the third part which investigates on an empirical basis how people deal with the ambivalences and tensions between these different orientations in the practice of online dating. Finally, a short conclusion questions if the boundaries between love and the market are being blurred or, in a fragile way, reestablished on the Internet today.
\end{abstract}

Key words: online dating, rationalization, romantic love, market, Internet, qualitative research, interviews, Germany, Switzerland

\begin{abstract}
Zusammenfassung:
In diesem Beitrag wird zunächst aufgezeigt, wie romantische Liebe und ökonomische Rationalität in der Moderne als zwei eigenständige Sphären entstanden, die durch je eigene normative Prinzipien, Erwartungen und praktischer Orientierungen gekennzeichnet sind und die zudem in der klassischen soziologischen Theorie zueinander systematisch als Gegensätze angesehen wurden. Im zweiten Teil wird analysiert, wie diese beiden eigenständigen Bereiche normativer Prinzipien und praktischer Orientierungen in das Feld des Online-Dating eingeführt werden. Dies führt dann zum dritten Teil, in dem empirisch untersucht wird, wie die Nutzer mit den Ambivalenzen und Spannungen zwischen diesen unterschiedlichen Orientierungen in der Praxis der Partnerschaftsbörsen umgehen. Die Schlussforderungen schließlich gehen der Frage nach, ob die Grenzen zwischen Liebe und Markt im Begriff sind, verwischt werden oder ob diese - auf jedoch brüchige Weise - im Internet heute wieder hergestellt werden.
\end{abstract}

Schlagwörter: Online-Dating, Rationalisierung, romantische Liebe, Internet, qualitative Forschung, Interviews, Deutschland, Schweiz 


\section{Introduction}

Within a few years, online dating has emerged in both public debates and in the social sciences as a new topic of questioning and scientific inquiry. In most cases, this form of relationship mediated by digital interfaces is presented as something radically new, dramatically transforming the romantic encounter as well as the ways subjects develop bonds of love or friendship. One of the assumptions made by researchers and observers of present transformations of digital activities is that these changes should signify an increase of a market relation between people: the current popularity of online dating is often seen as an effect of a general trend towards the rationalization of intimate relationships (Illouz 2007; Illouz/Finkelman 2009), the rise of the "entrepreneurial self" (Rose 1992; Arvidsson 2005) and the increasing dominance of consumerist culture in all areas of society (Baumann 2007).

The aim of this article is to discuss these assumptions on a theoretical as well as an empirical level. (I) In a first part, it will be argued that the questions raised today by online dating are not completely new because they reveal - in a specific way - fundamental normative tensions constitutive for modern societies in general. Here, romantic love and economic rationality have emerged as two distinct spheres characterized by their own normative expectations as well as practical orientations. A short sketch of how these two spheres were systematically opposed, not only in the practices of the people, but also in the perspective of almost all social theorists of the twentieth century will be outlined. (II) In a second part, it will be shown how these two distinct sets of normative principles and practical orientations are both introduced into the field of online dating. As a result, the Internet is not merely a new form of 'partner market' based on rationalistic and consumerist orientations. At the same time, it can be assumed that it represents a 'neoromantic media' that opens a whole new social space for romantic feelings and interactions. (III) The third part should underline these assumptions a little bit further on the basis of our empirical research. ${ }^{1}$ Hence, it will be analyzed how users are socialized into the world of online dating and what they learn about the ambivalences and tensions between different normative principles and practical orientations in this field. This will finally lead to a short conclusion questioning how the boundaries between the spheres of love and the market are being shifted, blurred or, in a fragile way, re-established in the practice of online dating.

1 The project is conducted in Switzerland in cooperation between the Université de Lausanne and the Institute for Social Research in Frankfurt am Main. It is funded by the Swiss National Science Foundation (No. 10015-122617/1).

We follow a qualitative research strategy that relies on different types of data: At first, the major dating sites in Switzerland were analyzed by means of an online ethnography and content analysis. Then, we conducted several in-depth interviews (up to 2.5 hours) with users of online dating. Until now, 12 interviews with men and women aged between 20 and 53 have been analyzed extensively, following the methodology of case-studies and grounded theory. All in all, about 25 interviews are planned until the middle of 2012. In addition to that, statistical data from several market research companies and results from other scientific studies have been collected and analyzed with regard to our research questions.

For more information about the project please visit our blog www.romanticentrepreneur.net 


\section{Love and the market as opposite spheres in modernity}

It is striking to see how most writers of classic sociological literature have systematically opposed two kinds of relationships, that is love and intimacy on the one hand, the market and instrumental relations on the other. The social sphere of intimate relationships of care and love as well as the family has been conceptualized in opposition to - sometimes even as a refuge from - the formal relationships that dominate the economic realm of the market. Max Weber, for instance, stated that love is "as radical as possible in its opposition to all functionality, rationality, and generality” (Weber 1946, p. 346). Pierre Bourdieu considers love as the "purest" practical realization of mutual recognition because it excludes self-interest, egoism and all kinds of symbolic power. Love means a suspension of strategic action between partners who make a "gift" of themselves in a relation of mutual trust (Bourdieu 1998, p.116). Niklas Luhmann (like Georg Simmel [1985] and others before) pointed out that love might offer "protection and support against the dominant characteristics of modern society - against the economic compulsion to work and exploitation, against the administration of the state, against a science that is shifting towards technology. The endangered self takes refuge in love” (Luhmann, 1997: 987², Luhmann 1986). This argument, still in vigor today, constructs the sphere of love and intimate relationships as a kind of 'counterworld' to the modern market society. Following this line, Anthony Giddens, for instance, describes the "pure relationship" as a dominant cultural ideal where the connection between partners is solely based on sexual and emotional attraction and liberated from any social or economic constraints (Giddens 1992). In the perspective of Elisabeth Beck-Gernsheim and Ulrich Beck, love has become a "secular religion" (Beck-Gernsheim/Beck 1995: 12) that promises salvation from the anomy that comes along with the process of individualization.

This conceptual opposition is not only based on theoretical considerations, but also on specific social transformations in the process of modernization. Many studies in history and sociology have analyzed how the emergence of a private sphere of intimacy, in contrast to the public sphere of the professional and economic life, has been the social condition for the development of relations based on the romantic ideal of love (Ariès/Duby 1999; Schurmanns 1998; Coontz 2005; Shorter 1975). While the public sphere has been increasingly dominated by formal relationships, instrumental rationality, bureaucracy and technology, contrastingly, romantic love and the values of personal intimacy, selfdisclosure, mutual care and interpersonal recognition have gained importance in the private sphere (Honneth 1996). In modern society, the "romantic utopia" (Illouz 1997) allows people to preserve the vision of an emotional transcendence of day-to-day instrumentalism by calling attention to mutual needs of care and intimacy within close relationships.

It is not our point here to expose in details those socio-historical changes that have led to this opposition between love and market but instead, we would like to sketch the main

2 Original in German: Liebe bietet „Schutz und Halt gegenüber den dominanten Merkmalen der modernen Gesellschaft - gegenüber wirtschaftlichem Zwang zur Arbeit und Ausbeutung, gegenüber staatlichen Regulierungen, gegenüber der ins Technologische drängenden Forschung. Das bedrohte Ich rettet sich in die Liebe.“ 
features of the two distinct normative principles, which relate to the spheres of love and market. In order to do so, it is helpful to point out three basic characteristics in which both principles are most radically opposed to each other. The principles of love and the market each constitute a relationship that substantially differs, first, in the way the subjects involved are constructed; second, in the motives and aims, which are generally assumed by the participants, and third in the level of abstraction that is characteristic for this type of interaction.

\section{Love's normative principle}

Love relationship's first feature deals with the fact that it undoubtedly implies connected beings contrarily to isolated beings conceived independently from the relation. An intersubjective dimension appears in the love relationship, between interdependent beings, which creates an open-mindedness of the subject towards the other as well as an expectation of reciprocity from the other (Benjamin 1988; Honneth 1996). As we will see later, self-disclosure plays a crucial role in the establishment of this particular form of intersubjectivity. In such a relationship, a subject's affective needs can only be satisfied in the common action between partners sharing the same affective values as frame. According to Hegel, this relationship can see the birth of such sensation as "unity of myself with another and of another with me" (Hegel 2001: 139). Affixed to this relation are norms controlling reciprocal stances according to which the "successful" love relationship excludes egocentrism, egotism, judgment and aloofness. From these norms, expectations and aspirations grow: if one of the relation's participant breaks this implicit "contract" of "disinterest" - for instance by defending one's interests to the detriment of the relation - it appears as an attack to this normative principle of love relationship (Honneth 1996). This is excluding the calculating subject only concerned with the maximization of one's own personal benefit.

The second feature deals with the autonomous nature of the relation and the exclusion of external factors. This relation is considered for itself, from the encounter and the longlasting bond made of closeness and intimacy between two beings - in one "unity of myself with another" (Hegel). Such insideness of the "successful" love relationship answers to a norm since the intervention of a third party (another person, law institution, etc.) in the love relationship is problematic and most likely to be criticized.

At third, it is important to express the singular and irreplaceable nature of the other in the love relationship. Indeed, the partners perceive themselves as unique, singular and "uninterchangeable" beings: the love relation excludes any form of abstraction (such as in trade, law or administration), thus requiring to take into account the singularity and uniqueness of the participants. Following this direction, it can stand as a "refuge" preserved from abstract and instrumental characteristics of social relations in modern societies. 


\section{Market's normative principle}

Contrarily to love, the market implies at first an isolated and calculating subject acting according to one's own interests in a competitive space. The market subject is an isolated, egotist and auto-referential subject. He or she needs another subject only as a support for the exchange and as a means of maximization of one's interests rather than in what the other is the intersubjective condition of himself or herself. The subject does not need others because he/she already exist with his/her own wishes and interests before the involvement in the exchange. Thus, this calculating and auto-sufficient actor takes for granted that the others show the same calculating attitude.

To this can be added that if the market, as highlighted by Weber (1978: 635), "represents a coexistence and sequence of rational consociations, each of which is specifically ephemeral insofar as it ceases to exist with the act of exchanging the goods", it means that it is ephemeral and a-social. The market exchange presumes a relation existing for the exchange and in the moment of the exchange only. Submitted to the market, the relation is determined by a purpose external to its social dimension, according to the heteronymous nature of the relation. A participant introducing social considerations in the exchange relation questions this exogenous trait of the exchange, namely, the normative principle of the market supposes a norm outside the social field.

At third, the relation specific to market is impersonal and abstract - it does not imply singular beings with affective strings. According to Weber, the market exchange is "the most impersonal of all relations of practical life in which men can be involved" and the market "only has considerations for things, not at all for persons neither for right of fraternity or pity, none either for primary human relations specific to personal communities" (Weber 1978: 641). The market is "radically estrange from any fraternity relation", it comes from "outside of neighborhood's community and any personal links" and it is in opposition with "all other forms of common life" in particular those revealing blood ties. Finally, only private ends determine market processes, erasing social bonds.

\section{The tension between love and the market}

The results of this general 'normative reconstruction' suggested here, radically oppose to one another the social spheres of love and the market. One has to keep in mind, though, that these normative principles have never been fully realized in the history of modern society. "The idea that arose on the threshold of the nineteenth century, opposing romantic love to the instrumental world of exchange relations, was probably always a typical product of bourgeois illusion” (Hartmann/Honneth 2006: 55).

As feminist studies have shown, the sphere of couple relationships and the family, which is generally seen as guided by the norms of romantic love, still includes specific forms of economic exploitation and domination (Delphy/Leonard 1992). At the same time, market relationships in modern society are not only governed by strictly rational forms of exchange, but also include a symbolic dimension and emotions as well as elements of a gift economy. Generally speaking, the normative principles of love and the market do not always fully correspond with the actual social practices in the respective fields. But still, these norms have a strong guiding force. As we have seen with feminism, 
they can serve as a base for criticism, which points to the discrepancy between the general ideal and the actual practice in a certain social sphere. If this criticism is successful, it also reaffirms the norm in question.

In recent times, there have been developments that seem to strengthen the boundaries between the social spheres of love and the market as well as processes, which tend to blur these distinctions. Since the late 1960s, the structure of the family and of couple relationships has fundamentally changed. By calling attention to the needs or wishes derived from the romantic ideal that the institutionalized practice of intimate relationships has hitherto failed to fulfill, social movements have criticized the traditional model of the bourgeois family, contributing to a deinstitutionalization of the nuclear family (Bernier 1996; Chaumier 2004). In addition to this, social and economic transformations have enabled a greater social mobility of individuals. This and the general rise of incomes have significantly diminished the social and economic constraints of couple formation, giving people more freedom to follow their own feelings in the choice of a partner. As a result, emotional quality and sexual attraction have significantly gained importance in contemporary love relationships (Giddens 1992: chap. 4; Beck-Gernsheim/Beck 1995). In general, these trends can be interpreted as a reinforcement of the romantic ideal of love and a strengthening of the boundaries between intimate relationships and other social spheres.

But there are also developments pointing in the opposite direction. In contemporary society, forms of economic rationality and market interaction tend to spread into many social areas. In sociology, this phenomenon is being discussed as the "tyranny of the market” (Bourdieu 1999) or - less polemic - as the "marketization of society" (Neckel 2001; Neckel/Dröge 2002) and the rise of a new "enterprise culture" (Heelas/Morris 1992; Keat/Abercrombie 1991). These developments also affect the private sphere. As Eva Illouz (1997) has shown, values and practices of consumer culture have increasingly entered the field of love - e.g. when people use consumer items and luxury goods to give their affective relationships a symbolic expression. Beside this, current developments in the sphere of work - e.g. the growing demand for 'flexibility' - are setting the private life under new constraints (Sennett 1998; Wimbauer 2010; Dröge/Somm 2005). But this blurring of boundaries also affects the realm of the market. Specific resources from the private sphere - e.g. "social skills", empathy, and creativity - have been carried over into the public sphere of work. "Emotional intelligence" (Goleman 1998) and emotional selfmanagement skills are often regarded as the key qualifications in today's business. As a result, the "commercialization of human feeling" (Hochschild 1983) has gained importance in work. Many authors, following Michel Foucault and the so-called 'governementality studies', have pointed out that these tendencies are also going along with a new concept of subjectivity: the idea of an "enterprising self" that shapes its existence through choices, that follows the ethics of individual responsibility, and that tries to optimize all areas of its personal life in regard to efficiency and economic rationality (Foucault 2004; Gordon 1991; Rose 1992; Bröckling 2007).

All this shows how difficult it is to analyze the actual relationship between romantic love and the market, especially if one looks at the way in which the boundaries between the different "value spheres" (Weber) and their corresponding normative principles are constantly shifted, blurred and reestablished. As a result, the relation between romantic love and the market is best described as a fundamental tension, which is both constitutive 
for modern society and yet unresolved - maybe even irresolvable in a more general sense. The necessity to deal with this tension seems to be a constant struggle and a driving force for social change. As we would suggest, the Internet is one place in today's society where this very struggle takes place.

\section{Love and the market on the Internet}

As mentioned above, the social change since the late 1960s has taken down many institutional restrictions in the sphere of intimate relationships, allowing more freedom in the choice of a partner as well as in the concrete form of the relationship (married or not, homo-, hetero- or bisexual, "polyamory" or monogamy, etc.). We have interpreted this as a reinforcement of the romantic ideal because it strengthened the autonomy of love against external regulations and restrictions.

Historically, this development was supported by a much more general social movement which was searching for new forms of self-realization and social experiences not only in love and sexuality, but also in culture, community and economic life. Interesting enough, the Internet and other electronic communication devices have also been interpreted in this direction - that is, as tools that widen the room for collective experiences and self-realization. With his concept of "virtual communities", Howard Rheingold (1993) has been, for instance, one of the first to defend the idea that Internet technologies allow the apparition of new forms of collectivity dealing with distant others estranged from co-presence. Referring - among others - to Marshall McLuhan (1962), Rheingold was convinced of the possibility of such practices to reinforce the social, collective, and communitarian life. He even hoped to improve sexuality by connecting people over the Internet (Rheingold 1991). In these early days, the ideas of counterculture movements in the USA were especially important for the interpretation of the social and cultural potential of this new media, creating what has later been called "the ideology" of the Internet (Turner 2006).

In a certain way, online dating practices also rely on this cultural and ideological framework. Within the last ten or fifteen years, this type of dating has become widely accepted in our society, making this business one of the few profitable sections of the Internet economy with a growth rate of 30-40\% p.a. (Jupiter Research 2008; NZZ 2007; Schmid 2006). It is obvious that the idea of freedom in the choice of a partner, which was very important for the sociocultural transformations described above, plays a crucial role in the cultural framing of online dating, too. One might even say that the Internet promises to continue - on a technological level - the liberation in the process of couple formation that started as a social movement in the late 1960s. In fact, this new media suggests that almost all remaining constraints, which are characteristic for classic places of couple formation, could be overcome (Geser/Bühler 2006; Hitsch/Horta/Ariely 2005; Fiore 2004). It offers an enormous amount of choices and makes it easy to contact people from all over the world. At the same time, it creates a very private situation: Sitting alone in front of his or her computer, a person seems to be more or less out of reach from the usual mechanisms of social control (family, colleagues, circle of friends) that can be restrictive in other forms of dating. Finally, online dating sites provide detailed information about 
each person involved (laid down in their digital "profiles"), which is supposed to help finding a person that exactly fits one's own personality. This idea of personal 'compatibility' of prospective partners, which is very prominent in the way dating sites describe and advertize their service, refers directly to the close connection between love and selfrealization that has been established as part of the sociocultural transformation of the 1960s and 1970s.

As we will see in the third part of this article, the promise of liberating and enlarging the possibilities for couple formation through the Internet can be very exciting and attractive for people, although it is often hard to get this promise fulfilled.

\section{The Internet as a neoromantic media}

Albeit there are many connections between sociocultural transformations in the field of love and the way online dating is interpreted and framed in our society, one thing is still irritating. Given the fact how important intimacy, emotions and sexuality has become in today's ideals of love (Giddens 1992), the question arises why people might choose a form of interaction which is mediated through technical interfaces to establish such an intimate relationship. It has often been highlighted that this mediated interaction is characterized by the fact that it brings people to relate to each other beyond their immediate copresence. Hence, those people do not share the same social and temporal frame. The disappearance of co-presence leads to some important consequences such as the less important role of the body in communication processes or the potentially anonymous nature of communication - aspects which, at first glance, seem to be completely contradictory to what we have outlined above as the main characteristics of the romantic ideal of love. Additionally, all interactions in this space inevitably are mediated by technological interfaces, thus any form of relation between two subjects must undergo the intermediary of digital platforms. Again, this seems totally contradictory to the specific immediacy of the relationship that the romantic ideal suggests.

As a result, computer mediated communication has often been regarded as a widely depersonalized and de-emotionalized form of human interaction (Döring 2003: 127 et seqq.); Walther 1996). Many classic views are based on the assumption that the reduction of communication channels in the text-based online conversation would lead to a certain kind of impersonality. Given the fact that direct body language is completely absent and hard to be recreated in computer networks,it seems to be particularly difficult to convey emotions.. As a result, this interaction is often described as task oriented and less influenced by power relationships or differences in social status (Sproull/Kiesler 1986; Rice/Love 1987). But it did not seem intended at all to build up intimate, close and longterm interpersonal relationships.

Nevertheless this position has been criticized early on, among others by the proponents of "virtual communities" (Rheingold 1993) on the net. The critics pointed to the fact that this emerging media has always been used not only for business or scientific purposes but also as a place to build up personal, intimate relationships (Jones 1995; Walther 1996). We would go even further and argue that the Internet is a kind of "neoromantic media" that fosters specific characteristics of interpersonal relationships, which are very close to what has been outlined above as core elements of the romantic ideal of love. 
What is of particular interest here, is the way in which the mediation through digital interfaces can support the specific form of intersubjectivity that the ideal of romantic love implies - despite the fact that this interaction seems so distant and impersonal in the first place. For this form of intersubjectivity, mutual self-disclosure plays a crucial role, and the Internet fosters this in a particular way (McKenna 2007; Joinson 2001; Ben-Ze'ev 2004: 34 et seqq.). Following the research of social psychology, there are two diametrically opposed constellations especially prone to extensive forms of self-disclosure: Ephemeral acquaintances which are not very deep nor long lasting - the so-called "stranger in the train phenomenon" - or relationships that are characterized by a special intimacy and mutual trust (Cozby 1973). What makes the Internet so particular is the fact that it combines elements from both constellations. On the one hand, users often see this media as a kind of secure space because they do not appear with their real names and have an easy-exit option anytime they want (Thurlow et al. 2004). This helps to overcome one's inhibitions and encourages self-disclosure - similar to the stranger in the train to whom we disclose ourselves just because we will most likely never meet him again (BenZe'ev 2004: 34 et seqq.; Döring 2003: 255 et seqq.; Ellison et al. 2006). On the other hand, the mediation through digital interfaces can - quite different from what one might expect - also lead to feelings of closeness, intimacy, familiarity and trust. The reason for this is that the reduced channels of online communication forces people to use their imagination to fill the informational gaps about the alter ego (Walther 1996). In the case of online dating, idealized images about the 'perfect partner' that people carry with them seem to be an important source for these imaginations - the virtual other becomes a projection screen for one's own wishes (Ben-Ze'ev 2004: pp. 78 et seqq.; Whitty/Carr 2003). As will be shown later on in greater details, this can lead to impressions of a particular closeness and familiarity in the relationship, which again augments the disposition for self-disclosure.

Over all, these characteristics of interactions mediated through digital interfaces can foster a certain form of intersubjectivity that shares some common characteristics with what the romantic ideal according to the normative principle of love suggests: relating to the other as a 'whole person' and not only as somebody playing a role, as an individual with whom one shares exclusive, intimate knowledge, etc. (Voirol 2010a). Obviously, some important elements are missing - especially that kind of visible and tactile experience of the body which is strictly bound at face-to-face (or body-to-body) interaction (Illouz 2007: 95 et seqq.). In part III of this article, we will have a closer look on the consequences of this absence - consequences that become especially problematic when the body comes into play as the relationship develops beyond the space of digital interfaces.

\section{Online dating as a partner market}

The present analysis considering the 'neoromantic' interactional forms of love on the Internet is only one perspective on the phenomenon of online dating. Major trends in sociological analyses describe it primarily in terms of the rational choice theory and the economics of the marriage market (Schulz/Skopek/Blossfeld 2010; Skopek/Schulz/Blossfeld 2009; Geser/Bühler 2006; Hitsch/Horta/Ariely 2005; Fiore 2004). Following this tradition, the process of mate selection in general and online dating in particular is character- 
ized as a form of market transaction where people exchange personal resources like education, social status, beauty, and so on, in order to maximize their individual utility. Of course, this perspective is heavily influenced by its theoretical background: the classic economics of the marriage market (Gale/Shapley 1962; Becker 1973, 1974, 1981). Nevertheless, there are other positions arguing against a quite different background which also stress the fact that forms of economic rationalization, consumerism and market relationships play a crucial role in online dating processes (see, for instance, Illouz 2007, Illouz/Finkelman 2009; Bauman 2007; Wetzel 2008)

As Eva Illouz has shown, the Internet makes the partner market as visible and 'tangible' a market like no other social setting before. Common places for getting in contact with potential partners outside the net - bars, parties or university campuses, but also traditional newspaper ads or dating agencies - have always been representing a very small portion of the partner market which, as a whole, stays invisible and abstract. In contrast, online dating sites are confronting their users instantaneously with the whole universe of options that are at stake in mate selection. Thousands of potential partners are directly 'at hand', for a contact requires only a few mouse clicks. "Whereas in the real world, the market of partners remains virtual - never seen, only presupposed and latent - on the net, the market is real and literal, not virtual, because Internet users can actually visualize the market of potential partners" (Illouz 2007: 87).

In fact, online dating sites address their users not only as romantic subjects, but also as economic actors who are looking for efficiency and a good bargain in mate selection (Dröge 2011). By the way they present the profiles of potential partners in exactly the same manner as items on eBay, Amazon or other shopping sites, with their complex search forms that allow to define the own preferences in mate selection with a precision unknown before, with the tools they offer to evaluate one's own market value and to enhance this value if possible - with all these elements borrowed from modern forms of consumerism and the economic sphere, they suggest a subject position which is very close to what we have outlined above as the main characteristics of a calculating subject in the realm of the market. It is the position of an economic agent who compares offers on a level of equivalence and tries to maximize his own interests. At the same time, it is the position of a self-marketing 'supplier' in a very competitive "economy of attention" (Franck 1999) with hundreds and thousands of direct rivals active on the site.

As will seen below, people may be able to distance themselves from this suggested subject position for a certain amount of time and follow the 'neoromantic' promises that the Internet also offers. But still, both the norms of the market and of the romantic ideal of love coincide in this field and people have to deal with the ambiguities and contradictions that arise from this. They must decide which orientation they are going to follow, and in turn, insure that their interactional partners share the same "definition of the situation" (Goffman 1974) - whether this may be a certain form of market-like exchange or a romantic encounter with their respective corresponding rules and normative expectations. As we have mentioned above, these problems are not new to modern society. But online dating 'reenacts' the tension between love and the market in a specific manner. 


\section{The practice of online dating - romantic expectations and processes of rationalization}

When people enter the field of online dating, they are being socialized into the specific rules, routines and norms of this particular social space. In this process, they also have to deal with the normative and practical tensions between love and the market present here. They are addressed as romantic subjects, searching for intimacy and an exclusive love relationship. But at the same time, they are confronted with innumerable competitors in an anonymous market environment in which they must assert themselves. So how do people find their way into this complex space?

According to most contemporary scientific literature, the answer seems clear. As we have already mentioned, the current popularity of dating on the net is often seen as the result of a consumerist or rationalistic approach to intimate relationships. In fact, these rational and consumerist orientations play an important role in online dating, so there is some truth in these diagnoses. Nevertheless, we would reject the assumption that these orientations are the main driving force or motivation for people to enter the field of online dating. On the contrary, our empirical data strongly suggests that in the first place, most people are attracted by what we have called the "neoromantic" aspects of the media, whereas more rationalist orientations come into play later on. This could be described as a typical "career" in the usage of online dating, as a temporal pattern that - despite all individual differences - is fundamental with regard to the way people deal with the chances and pitfalls of this new means of seeking a partner. Further on, it is assumed that this temporal pattern results from a certain learning process in which specific frustrations about the non-deliverance on the promises of the "neoromantic" media lead to a more rationalist approach to online dating. This assumption will be explained in greater detail below.

To begin with, it is relevant to show how people experience the "neoromantic" aspects of the media and what makes them so attractive in the first place. Thinking about this, one has to keep in mind that people often start their journey into online dating out of a situation of loneliness and sometimes even frustration about the lack of opportunities to meet interesting people in their everyday life. They might have a lot of social contacts our respondents often stress the fact that they are no geeky computer nerds nor loners but on the contrary, very well-embedded in social networks. Nevertheless, they often feel being stuck in their restricted world of friends and colleagues. When they sign up on an online dating site, this small world is suddenly widened and hundreds and thousands of new people enter their field of vision. A whole new social sphere opens up where it is very easy to get in touch with as many people as one likes and from all around the world. Here, a general characteristic of the Internet comes into play: its capacity to enlarge social circles in a way that is not very different from early times of modern society, when urbanization and industrialization entailed similar social ruptures (Voirol 2010b).

Some users of online dating are overwhelmed by these new possibilities. But in general, many of our respondents experience it as a long-awaited escape from a rather frustrating situation they have fallen into. This can be very exciting and users often describe that they were rapidly sucked into this new sphere - sometimes even to an extent that they consider it as a form of addiction. They may spend hours browsing the site, observing 
who is visiting their own profile and writing messages to people that they would have never met otherwise. Already at this early stage in the usage of online dating, the Internet offers a certain "counterworld", that is, a way of stepping out of everyday life and experience a form of "extraordinariness" that is also a substantial part of our modern ideal of romantic love in general (Weber 1946: 346).

This experience of "extraordinariness" is often reinforced when people start to communicate with others on the site. To say it with the words of $\mathrm{Carol}^{3}$, a nurse in the midforties who first explored about ten years ago the world of online dating: "I was fascinated by the attraction that may develop out of something that's just text, you know? Without ever hearing the voice, without knowing how the person looks like.”

Like Carol, many of our interviewees describe it as an intriguing and sometimes surprising experience: how rapidly feelings of intimacy and close togetherness can arise in online relationships - feelings, that are sometimes even considered as being deeper and more intense than they are outside the Internet. Here, the exact same mechanisms that we have described above as the "neoromantic" potential of the new media come into play. "Something that's just text" develops into a projection screen for one's own wishes concerning a prospective partner. Fantasy and imagination get activated and idealization processes begin to arise. What has been a frustrating situation of loneliness now tends to be transformed into the exact opposite: an overabundance of likeminded people that can be imagined as possible companions in a loving relationship. Again, this is exciting and draws people even deeper into the world of online dating.

But there is also something else at stake here. As we have outlined above, online communication in general is often prone to rapid and extensive self-disclosure. Such is also the case in dating environments. Carol is again a good example here when talking about a very close friend of hers that she got to know over the Internet a few years ago: "We have never met face to face, but he's a guy, there is almost nobody out there knowing me as good as he does. He knows so much about me."

In fact, this guy is rather a 'best friend' for her, somebody to call or email in the middle of the night when she is in trouble. As he is homosexual, having an intimate relationship was at no time really an option and they never met other than over the Internet or the telephone. Yet, she made similar experiences with other people - albeit not so deep and not for so long, because after a while a face-to-face encounter seemed unavoidable. Nevertheless, it is interesting to see (not only in this case) which amount of self-disclosure and intimacy might develop in pure online communication where people have not yet met outside the Internet.

Mutual self-disclosure is crucial for the process of falling in love and building up a love relationship. There is plenty of literature about this topic from psychology as well as sociology. A classic study comes from Peter Berger and Hansfried Kellner, who analyzed the process of couple formation in their work on "Marriage and the construction of reality" (Berger/Kellner 1964). From the perspective of a microsociology of knowledge, Berger and Kellner argue that intense "conversations" in which people disclose themselves and share their everyday worldview play a crucial role in developing a common identity as a couple and stabilizing their relationship. We all know these extensive conversations

3 All names have been changed. 
about one's own personal experiences, about everyday opinions, personal tastes and idiosyncrasies from early stages of couple relationships. Berger and Kellner interpret this as a "nomic process" (ibid.: 11) in which the emerging couple adjusts their respective "constructions of reality" to each other in order to develop a common worldview. This, in turn, transforms also the identity of the two people involved and helps to establish the specific form of intersubjectivity that the romantic ideal suggests. Each person now becomes part of an exclusive unit, which is distinctive from any other social relationship they are engaged in.

Of course, Berger and Kellner could not foresee the development of the Internet in the sphere of intimate relationships when they wrote their study in 1964 . Nevertheless, their concepts can be very helpful in analyzing today's online relationships. In fact, one might say that with online dating, the "nomic process" of developing a common worldview and an identity as a couple already starts to emerge within the mediated environment. Especially if people are rather new to this type of dating, they tend to dive deeply into online conversations, chatting and emailing extensively with mostly one, sometimes a few significant others. This can increase to the point where they virtually participate in the everyday life of the other, exchanging messages at least every few hours about what they are currently doing, thinking or experiencing.

Jenny for instance, a media consultant from Germany currently living in Switzerland, made her first experiences with online dating by emailing several months with a guy from Dubai before they actually met. Being an expatriate from Germany, he shared his everyday experiences of strangeness with her. She was at that time working on her diploma thesis, and shared the woes of this task with him. In the end, they wrote about twenty emails each day. Although they never met outside the Internet up to that day, their lives were still closely interconnected and the respective other was an integral part of it. One can really say that in a certain sense, they became a couple before they actually met outside the Internet. "I was fascinated by that man”, Jenny said in the interview, "I totally fell in love".

What is going on here and in many other cases is that, as a result of an intense and long lasting "conversation” over the Internet, the specific self-transformation that Berger and Kellner are describing already begins. One's own "construction of reality" is confronted with, widened and to some degree even transformed by the one of a significant other, to whom one is closely connected over the Internet. Again, this can be very intriguing and brings “extraordinariness” into everyday life - even up to a point where one's own identity gets affected (Dröge 2010). In Jenny’s case, this went so far that she eventually decided to live in Dubai for three months to finish her diploma thesis there. Before that, the two had met for a few days in Germany. But still, the established online relationship was the decisive factor for her. From today's standpoint, she describes it as a "huge bubble" - "strange how one can be obsessed with an image of somebody". But at that time, the relationship was very important for her and had a huge impact on her personal life.

Overall, one can conclude that the Internet really constitutes a new and exciting "seductive space”, as Aaron Ben-Ze’ev (2004: 1) puts it. It opens up a whole new social sphere for romantic feelings and experiences - beginning with the widening of social circles and a certain type of "extraordinariness" it brings into everyday life, continuing with 
the large room it gives for imagination, projection and idealization of the respective other, and additionally reinforced by the processes of mutual self disclosure and the identitarian transformations that may arise from them.

\section{Disappointments, learning processes and economic rationalization}

Although the Internet can be considered as a 'neoromantic' social space, there are also a lot of difficulties and the disappointment of the romantic expectations is often waiting just around the corner. Of course, it is by no means special to this new media that emerging love struggles with doubts and potential disappointments. But still, online dating has a few specific pitfalls that are closely connected to romantic expectations it fosters in the first place.

Among these pitfalls, one situation stands out in being probably the most difficult and often disappointing moment in the process of becoming a couple over the Internet: the first face-to-face encounter. Virtually all our respondents have made curious experiences with this situation. Oftentimes, the irritations seem minor at first sight. The other person might have a strange sounding voice or an odd bodily behavior, be much taller or smaller than anticipated, look older, more "dressed up", less cute than expected, or might not be as eloquent or communicative as before. "You build up an image of somebody. ... But oftentimes it simply doesn't fit”, Jenny says, describing an experience that is shared by many of our respondents.

Despite the fact that these irritations may seem marginal, they can have severe consequences. No matter what the actual problem is - the first face-to-face encounter mostly disturbs the image of the respective other in a very fundamental way. It is rarely the case that the feelings of intimacy and togetherness developed online seamlessly cross the border to the offline encounter. On the contrary, these feelings often collapse very fast when people meet outside the net, and it can be very hard or even impossible to reestablish them again (for similar observations see also: Illouz 2007; Herlyn 2001).

Given how strong these feelings can be in the first place, this sudden collapse is a very irritating and disappointing experience. People express their disappointment in different ways: they may accuse the other person of not having been authentic, honest or truthful before, they may question the reality status of online interaction in general or blame themselves for being too naïve. Carol concludes: "That's kind of a parallel universe, you know? Hard to describe. It's a dream world, nothing real, no. ... You can read into it something about the man or woman of your dreams, you mold it into place. You are sculpting the other into Mr. Right, yeah. And then you meet him and he is anything but this."

As this quotation shows, the discrepancy between the romantic expectations and the actual experiences can lead to a fundamental change in the attitude towards the Internet. What has been a sphere of exiting romantic experiences now tends to become an illusionary, unreal world, a "parallel universe" as Carol puts it, which contains a huge potential for disappointment and frustration. The intense online "conversations" which were believed to foster self disclosure and mutual understanding now appear more like monadic soliloquies where one communicates with one's own projections rather than with a real counterpart. Finally, the feelings of intimacy and togetherness that are developing online 
now become not only questionable but also potentially dangerous, because they tend to draw people into a world of false emotions and illusions. It seems as if the classic idea of "amour fou" is reactivated here - love as a dangerous passion that makes people lose touch with reality and go insane. But classic forms of "amour fou" are usually regarded as mainly driven by the body and the sexual desire - this makes them so dangerous and exiting at the same time (Breton 1949). On the Internet though, it is not the dominance but the absence of the body that causes the problems. People experience their passion as dangerous and illusionary simply because the emotions are initially detached from bodily copresence, and the bodily experience and sexual desire cannot catch up with them in the face-to-face encounter.

As a result of the fundamental change in her point of view on the romantic potential of the Internet, Carol has now abandoned all her activity in the field of online dating. But this has not been her first reaction. She struggled nearly ten years with this decision, trying to learn the lessons and be more cautious or even stay away from the Internet for a while - but the exciting aspects of online dating always recaptured her.

It is very common that people try to develop some sort of protective measures against the disappointing experiences they made with online dating. First and foremost, this implies a certain form of self-discipline that should help to distance oneself from the dangerous feelings emerging in the virtual sphere. People talk about cooling down their emotions, being more realistic and aware of one's own projections, preparing oneself for the "shock" of the first face-to-face encounter, and so on. "You learn very fast that you shouldn't expect too much”, our respondent Robert explains in the interview - this also implies that a freefloating romantic imagination on the Internet is not only a problem experienced by women, such as common preconception might suggest. "That's because you are projecting, you already develop an image of that person. ... You have to retain yourself a bit, not always easy." During the interview, he started the computer and opened up his profile on an online dating site to show how it works. As he was browsing through the new messages and the list of recent visitors of his profile, it was impossible to overlook how hard it was for him to keep his imagination and emotions under control. "Hey no, that's not true! This one is really cute!” he shouted out, spotting a new face in the list of recent visitors. But instantly, he reminded himself: "Well, yes, it's always, you have to rein in a bit".

As we can see here and in many other cases, controlling imagination and emotions is a constant struggle while exploring the sphere of online dating. As outlined above, this has to do with the very nature of this "seductive space" (Ben-Ze'ev 2004) that fosters imagination, projection and romantic feelings in a specific way. But at the same time, online dating also suggests a 'solution' for this common problem. We are talking here about the different rationalistic techniques and tools that promise to overcome the irrationality of emotions, intuition, imagination and idealization in the process of partner selection. For this purpose, online dating sites offer a vast array of information about each and every member of their community. Advanced filtering techniques also allow for adjusting the selection of prospective partners very precisely in order to assure a common social, financial and educational background, similar hobbies and lifestyle, shared interests and opinions (Dröge 2011). All these techniques should help to reduce the uncertainty of love in general and online dating in particular. They promise to avoid disappointments, illusions and false expectations and make the partner selection a well-considered, sane and rational 
choice. In fact, people are using these rationalistic tools and techniques as a central part of their strategy of self-discipline. This is what we have called above a 'learning process' in which rationalization processes emerge as an attempt to overcome the disappointments that result from the romantic expectations, which tend to attract people first.

Jenny for instance, the woman who once emailed with her virtual mate in Dubai for several months before meeting him face-to-face, is now trying to drastically cut down the time she invests in an online relationship. In order to do so, she developed a very systematic and methodic approach to online dating. In a first step, she adjusts the filtering criteria properly so that only a few hundred profiles remain on a certain dating site. With a quick run-through, she reduces these few hundred profiles to a short list of about thirty. Then, she writes brief messages to all of them, waiting for the answer to decide whom she will meet in person. With this method, she explains, one is able to "graze" a whole site in only one evening.

In a very similar manner, the interviewee Miriam reports that her "strategy improved much" over time: "Today, I'm able to scan a profile in two minutes. ... I am ticking off my checklist." Also, she has now learned that it is a "waste of time" to write long emails back and forth because it constructs an image of somebody that is not reliable anyway. Instead, she meets people as soon as possible. This again leads to the problem that attending all these dates is very time-consuming. So she has become much more "choosy" with regard to the people she considers appropriate for a date. Furthermore, she optimized the very process of dating by meeting people only during her lunch break. This limits the time she has to invest to the one hour break at maximum, whereas dates in the evening can take much longer because they do not have a predefined end.

What becomes obvious in the considerations of Jenny and Miriam quoted here, is a certain idea of efficiency and economy of time that we find in many interviews. This idea is a good example of how concepts and routines from the realm of the market, from the sphere of work and mass consumption enter the field of personal relationships on the Internet. In order to understand what is happening here, it is important to see that the strategy of efficiency has a dual meaning in this particular situation. On the one hand, it reacts to the overabundance of potential partners available on the Internet. In fact, online dating exposes people to a "tyranny of choice" (Fiore 2004: 24 et seqq.; Schwartz 2004): If there are more options than a person can actually explore, choosing becomes inherently difficult. Advanced selection strategies have to be applied - techniques that are usually more common in the field of mass-consumption than they are in romantic encounters (Illouz 2007: 86 et seqq.; Arvidsson 2005).

On the other hand, the strategy of efficiency also answers to the disappointment of the romantic ambitions that we outlined above. First, it replaces quality by quantity. Instead of diving deeply into an intense emotional relationship with a single alter ego as the romantic ideal would suggest, the strategy multiplies the options by contacting more people with less intensity. This should then reduce the potential disappointment if one of these options fails. This however introduces a form of abstraction into the interactions which is, as outlined above, rather characteristic for social relationships in the realm of the market than for love.

Secondly, the attempt to cut down the time of the online conversation should also allow dangerous emotions and illusions as little room as possible to develop. As Robert 
concludes, "the less projection the better it is. Establish a contact and meet the person right away, that's the best”. Finally, this strategy tries to control one's own feelings by confronting them with the 'hard facts' laid down in the profiles and by relying on preconfigured selection criteria, rather than on what emerges in the conversation. Here, rationalization techniques are used as a kind of disciplinary tool to prevent one's own feelings from losing touch with reality.

In a more general sense one can say that people adopt routines and strategies from other social spheres - notably that of market relationships, work and consumerism - in order to cope with the problems they face in their romantic ambitions on the Internet. In her research, Eva Illouz also found a lot of evidence for this. Her respondents used economic metaphors and analogies to describe their experiences with online dating, e.g. when they compared a rendezvous with a job interview where they apply the same techniques to market themselves to a potential employer (Illouz 2007: 87 et seq.). In our own study, several people compared online dating with shopping on the Internet: "It occurs to me as if you are choosing a digital camera, you know?”, Carol explains, "you get offers and comparisons. This suits me and that, this and that. I don't know, it doesn't seem right for me somehow."

\section{Conclusion}

In the above quotation, the last sentence from Carol is particularly interesting. It shows that even if rationalization techniques seem to solve some of the problems that come together with the romantic expectations fostered by the Internet, they also introduce new irritations and difficulties. This can be seen in many of our interviews. The norm of romantic love does not simply disappear during the 'learning process' described above but it remains, making people feel that something “doesn't seem right” if they rely too much on strategies and routines from the sphere of market relationships and consumerism. The tension between love and the market is apparently unsolvable but produces a difficult double-bind situation. Each side seems to offer 'solutions' for the problems of the respective other side but introduces new difficulties at the same time. Being more rationalistic and self-disciplined promises to avoid that the romantic feelings are becoming insane, but also distances oneself from what was the initial ambition of the whole project - that is, entering into an exclusive and intimate relationship with a beloved other. Moving more towards the 'romantic' side of the spectrum may help to come closer to this goal and to experience forms of intimacy and closeness that can be very exciting. But it also nurses doubts whether these feelings eventually are 'real' and can be translated into a stable offline relationship.

Given how close romantic interactions and rational strategies are intertwined in this particular situation, one might ask if it is still useful to distinguish the two in such a strict manner as we suggested in the first part of this article. Following this doubt, online dating would be interpreted as a current example of how the boundaries between the social spheres of love and the market are blurred or even completely disappear.

From our point of view, such an interpretation would be wrong for two major reasons. At first, it would not allow for understanding the particular excitement that most people 
experience when they first enter the field of online dating. This excitement mostly relies on the 'neoromantic' promises that the new media implies. If people would no longer be able to distinguish between a situation ruled by the romantic ideal and a more rational approach to love and intimate relationships, then these promises would not be as appealing as they are. Secondly, such an interpretation would not allow for explaining why people are so strongly disappointed if their romantic ambitions are not fulfilled on the Internet and why they express a feeling of unease if they move too much towards the rational and strategic side of the spectrum of possible orientations. This again points to the fact that the romantic ideal of love is still in vigor today and that people derive expectations from this ideal, which then leads to being disappointed. It is for these very reasons that we do not see the differences between romantic love and the market as completely blurred. Instead, the Internet seems to be a contemporary arena where the fundamental tension between both normative principles is being 'reenacted' under particular new circumstances.

\section{References}

Ariès, P. \& Duby, G. (1999). Histoire de la vie privée. Paris: Seuil.

Arvidsson, A. (2005). Quality singles: Internet dating as immaterial labour (Cultures of consumption, Working paper series). http://www.consume.bbk.ac.uk/working_papers/ArvidssonReality.final.doc [retrieved: 2007-02-12].

Bauman, Z. (2007). Consuming life. Cambridge: Polity Press.

Benjamin, J. (1988). The bonds of love. New York: Pantheon.

Becker, G. S. (1973). A theory of marriage: Part I. Journal of Political Economy, 81, 4, pp. 813-846.

Becker, G. S. (1974). A theory of marriage: Part II. Journal of Political Economy, 82, 2, pp. S11-S26.

Becker, G. S. (1981). A treatise on the family. Cambridge: Harvard University Press.

Beck-Gernsheim, E. \& Beck, U. (1995). The normal chaos of love. Cambridge: Polity Press.

Ben-Ze'ev, A. (2004). Love online. Emotions on the Internet. Cambridge: Cambridge University Press.

Berger, P. \& Kellner, H. (1964). Marriage and the construction of reality: An exercise in the microsociology of knowledge. Diogenes, 12, pp. 1-24.

Bernier, L. (1996). L’amour au temps du démariage. Sociologie et sociétés, XXVIII, 1, pp. 47-61.

Bourdieu, P. (1998). La domination masculine. Paris: Seuil.

Bourdieu, P. (1999). Against the tyranny of market. New York: The New Press.

Breton, A. 1949 [1937]. L'amour fou. Paris: Gallimard.

Bröckling, U. (2007). Das unternehmerische Selbst. Soziologie einer Subjektivierungsform. Frankfurt am Main: Suhrkamp.

Chaumier, S. (2004). La déliaison amoureuse: de la fusion romantique au désir d'indépendance. Paris: Payot \& Rivages.

Coontz, S. (2005). Marriage, A history: From obedience to intimacy, or how love conquered marriage. New York: Viking.

Cozby, P. C. (1973). Self-disclosure: A literature review. Psychological Bulletin, 79, 2, pp. 73-91.

Delphy, C. \& Leonard, D. (1992). Familiar exploitation: A new analysis of marriage in contemporary Western societies. Cambridge: Polity.

Döring, N. (2003). Sozialpsychologie des Internet. Die Bedeutung des Internet für Kommunikationsprozesse, Identitäten, soziale Beziehungen und Gruppen. Göttingen: Hogrefe (2., vollständig überarbeitete und erweiterte Auflage).

Dröge, K. \& Somm, I. (2005). Spurlose Leistung. Langsicht im flexiblen Kapitalismus. bios, 18, 2, pp. 215-235.

Dröge, K. (2010). Romantische Unternehmer im Netz. Widersprüchliche Identitätsangebote beim Online Dating. WestEnd. Neue Zeitschrift für Sozialforschung, 7, 2, pp. 82-94. 
Dröge, K. (2011, forthcoming). Transitorische Sozialbeziehungen oder: Wider die Ungleichheitsblindheit der Internetsoziologie In: Stegbauer, C. (Ed.), Ungleichheiten aus medien- und kommunikationswissenschaftlicher Perspektive. Wiesbaden: VS Verlag für Sozialwissenschaften.

Ellison, N., Heino, R. \& Gibbs, J. (2006). Managing impressions online: Self-presentation processes in the online dating environment. Journal of Computer-Mediated Communication, Vol. 11, No. 2.

Fiore, A. R. T. (2004). Romantic regressions. An analysis of behavior in online dating systems. Boston: Massachusetts Institute of Technology. http://www.ischool.berkeley.edu/ atf/thesis_mit/fiore_thesis_ final.pdf [retrieved: 2007-02-15].

Foucault, M. (2004). Naissance de la biopolitique: cours au Collège de France (1978-1979). Paris: Gallimard \& Seuil.

Franck, G. (1999). The economy of attention. Telepolis, 07.12.1999. http://www.heise.de/tp/r4/artikel/ 5/5567/1.html, [retrieved: 2009-01-21].

Gale, D. \& Shapley, L. S. (1962). College admissions and the stability of marriage. American Mathematical Monthly, 69, 1. pp. 9-15.

Geser, H. \& Bühler, E. (2006). Partnerwahl Online. http://socio.ch/intcom/t_hgeser15.pdf [retrieved: 2007-02-15].

Giddens, A. (1992). The transformation of intimacy: Sexuality, love and eroticism in modern societies. Cambridge: Polity.

Goffman, E. (1974). Frame analysis: An essay on the organization of experience. New York: Harper \& Row.

Goleman, D. (1998). Working with emotional intelligence. New York: Bantam Books.

Gordon, C. (1991). Governmental rationality: An introduction. In: Burchell, G., Gordon, C. \& Miller, P. (Eds.), The Foucault effect. Studies in governmental rationality. London: Harvester Wheatsheaf, pp. 1-52.

Hartmann, M. \& Honneth, A. (2006). Paradoxes of capitalism. Constellations, 13, 1, pp. 41-58.

Heelas, P. \& Morris, P. (Eds.) (1992). The values of the enterprise culture. The moral debate. London/New York: Routledge.

Hegel, G. W. F. (2001) [1821]. Philosophy of right. Ontario: Batoche Books

Herlyn, G. (2001). Partnersuche im Internet. Mediale Mythenbildung und Aneignungserfahrungen einer alltäglichen Kommunikationstechnik. Kommunikation@Gesellschaft, 2. http://www.kommunikation- gesellschaft.de [retrieved: 2006-10-04].

Hitsch, G. J., Horta, A. \& Ariely, D. (2005). What makes you click: An empirical analysis of online dating. http://www.aeaweb.org/annual_mtg_papers/2006/0106_0800_0502.pdf [retrieved: 2007-02-15].

Hochschild, A. Russell (1983). The managed heart. Commercialization of human feeling. Berkeley: University of California Press.

Honneth, A. (1996). The struggle for recognition: The moral grammar of social conflicts. Cambridge: The MIT Press.

Illouz, E. \& Finkelman, S. (2009). An odd and inseparable couple: Emotion and rationality in partner selection. Theory and Society, 38, pp. 401-422.

Illouz, E. (1997). Consuming the romantic utopia. Love and the cultural contradictions of capitalism. Berkeley: University of California Press.

Illouz, E. (2007). Cold intimacies. The making of emotional capitalism. Cambridge: Polity Press.

Joinson, A. N. (2001). Self-disclosure in computer-mediated communication: The role of self-awareness and visual anonymity. European Journal of Social Psychology, 31, 2, pp. 177-192.

Jones, S. G. (Ed.) (1995). CyberSociety. Computer-mediated communication and community. Thousand Oaks: Sage.

Jupiter Research (2008). German online dating services generate a turnover of 85 million Euros. http://www.just4business.eu/2008/02/german-online-dating-services-generate-a-turnover-of-85million-euros/ (February 23, 2008).

Keat, R. \& Abercrombie, N. (Eds.) (1991). Enterprise culture. London/New York: Routledge.

Luhmann, N. (1986). Love as passion: The codification of intimacy. Cambridge: Polity.

Luhmann, N. (1997). Die Gesellschaft der Gesellschaft. Frankfurt am Main: Suhrkamp.

McKenna, K. Y. A. (2007). A progressive affair: Online dating to real world nating. In: Whitty, M. T., Baker, A. J. \& Inman, J. A. (Eds.), Online matchmaking. Houndmills: Palgrave Macmillan: 112-124. 
McLuhan, M. (1962). The Gutenberg galaxy. The making of typographic man. Toronto: University of Toronto Press.

Neckel, S. (2001). „Leistung“ und „Erfolg“. Die symbolische Ordnung der Marktgesellschaft. In: Barlösius, E., Müller, H.-P. \& Sigmund, S. (Eds.), Gesellschaftsbilder im Umbruch. Soziologische Perspektiven in Deutschland. Opladen: Leske + Budrich, pp. 245-265.

Neckel, S. \& Dröge, K. (2002). Die Verdienste und ihr Preis: Leistung in der Marktgesellschaft. In: Honneth, A. (Ed.), Befreiung aus der Mündigkeit. Paradoxien des gegenwärtigen Kapitalismus. Frankfurt am Main/New York: Campus, pp. 93-116.

NZZ (Neue Zürcher Zeitung) (2007). Online zum Liebesglück. NZZ am Sonntag, March 11, 2007.

Rheingold, H. (1991). Teledildonik: Die totale Erotik. In: Waffender, M. (Ed.), Cyberspace. Ausflüge in virtuelle Wirklichkeiten. Reinbek bei Hamburg: Rowohlt, pp. 178-182.

Rheingold, H. (1993). The virtual community. Homesteading on the electronic frontier. Reading: Addison-Wesley.

Rice, R. E. \& Love, G. (1987). Electronic emotion: Socioemotional content in a computer-mediated network. Communication Research, 14, 1, pp. 85-108.

Rose, N. (1992). Governing the enterprising self. In: Heelas, P. \& Morris, P. (Eds.), The values of the enterprise culture. The moral debate. London/New York: Routledge.

Schmid, C. (2006). Internetdating-Plattformen: Suche nach der Liebe per Mausklick rentiert In: Handelszeitung, August 2, 2006.

Schulz, F., Skopek, J. \& Blossfeld, H.-P. (2010). Partnerwahl als konsensuelle Entscheidung. Kölner Zeitschrift für Soziologie und Sozialpsychologie, 62, 3, pp. 485-514.

Schurmans, M.-N. (1998). Le coup de foudre amoureux. Essai de sociologie compréhensive. Paris: PUF.

Schwartz, B. (2004). The tyranny of choice. Scientific American, April 2004, pp. 70-75.

Sennett, R. (1998). The corrosion of character. The personal consequences of work in the new capitalism. New York: Norton

Shorter, E. (1975). The making of the modern family. New York: Basic Books.

Simmel, G. (1985). Fragment über die Liebe. In: Simmel, G.: Schriften zur Philosophie und Soziologie der Geschlechter. Frankfurt am Main: Suhrkamp, pp. 224-282.

Skopek, J., Schulz, F. \& Blossfeld, H.-P. (2009). Partnersuche im Internet. Bildungsspezifische Mechanismen bei der Wahl von Kontaktpartnern. Kölner Zeitschrift für Soziologie und Sozialpsychologie, 69, 2, pp. 183-210.

Sproull, L. \& Kiesler, S. (1986). Reducing social context cues: Electronic mail in organizational communication. Management Science, 32, 11, pp. 1492-1512.

Thurlow, C., Lengel, L. \& Tonic, A. (2004). Computer-mediated communication: Social interaction and the Internet. Thousand Oaks: Sage.

Turner, F. (2006). From counterculture to cyberculture: Stewart Brand, the Whole Earth Network, and the rise of digital utopianism. Chicago: University of Chicago Press.

Voirol, O. (2010a). Digitales Selbst: Anerkennung und Entfremdung im Netz. WestEnd. Neue Zeitschrift für Sozialforschung, 7, 2, pp. 106-120.

Voirol, O. (2010b). Die Ambivalenz der «digitalen Gesellschaft». Über die Erweiterung und Vervielfältigung der sozialen Kreise im Internet. Neue Zürcher Zeitung (NZZ), October 23, 2010.

Walther, J. B. (1996). Computer-mediated communication: Impersonal, interpersonal, and hyperpersonal interaction. Communication Research, 23, 3, pp. 3-43.

Weber, M. (1946). From Max Weber: Essays in sociology. New York: Oxford University Press.

Weber, M. (1978) [1922]. The market: Its impersonality and ethics. In: Weber, M.: Economy and society: An outline of interpretive sociology. Berkeley/Los Angeles: University of California Press, pp. 635-640.

Wetzel, D. J. (2008). „Ich hab ihn...?“ Emotionen/Affekte beim Onlinedating und bei der Partnerwahl. Poststrukturalistische Zugänge (Vortrag auf dem 34. Kongress der Deutschen Gesellschaft für Soziologie, Jena, 7.10.2008, Adhoc-Gruppe: Onlinedating - Neue Wege der Partnerwahl). http:// www. soz.unibe.ch/unibe/wiso/soz/content/e5976/e7254/e8637/e8647/files11834/Vortrag. onlinedating.Jena.7.10.2008.pdf [Retrieved; 2011-12-12]. 
Whitty, M. T. \& Carr, A. N. (2003): Cyberspace as potential space: Considering the web as a playground to cyber-flirt. Human Relations, 56, 7, pp. 869-891.

Wimbauer, C. (2010). Subjektivierte Arbeit und die „Tücken“ der Anerkennung in DoppelkarrierePaaren. In: Frey, M., Heilmann, A., Lohr, K., Manske, A. \& Völker, S. (Eds.), Perspektiven auf Arbeit und Geschlecht. Transformationen, Reflexionen, Interventionen. München/Mering: Rainer Hampp Verlag, pp. 165-187.

Submitted on/Eingereicht am 19.04.2011

Accepted on/Angenommen am 22.09.2011

Addresses of the authors/Anschriften der Autoren;

Kai Dröge, M.A. (Corresponding author/Korrespondenzautor)

Senior SNSF Researcher

Université de Lausanne

Institut des sciences sociales

Quartier UNIL-Dorigny, Anthropole 3093

1015 Lausanne

Switzerland/Schweiz

Olivier Voirol, Ph.D.

Senior Lecturer

Université de Lausanne

Institut des sciences sociales

Quartier UNIL-Dorigny, Anthropole 3119

1015 Lausanne

Switzerland/Schweiz

E-Mail: K.Droge@unil.ch

Olivier.Voirol@unil.ch 